\title{
MRI-Guided Focused Ultrasound Ablation
}

National Cancer Institute

\section{Source}

National Cancer Institute. MRI-Guided Focused Ultrasound Ablation. NCI Thesaurus.

Code C62723.

An image-guided, non-invasive technique that uses high energy ultrasound to treat tumors by thermoablation. 